\title{
Angiotensin II-Superoxide Signaling and Arterial Baroreceptor Function in Type-1 Diabetes Mellitus
}

Yu-Long $\mathrm{Li}^{*}$

Department of Emergency Medicine, University of Nebraska Medical Center, USA

\begin{abstract}
Diabetes is a major world health problem. Growing evidence from both clinical trials and animal experiments has clearly confirmed that arterial baroreflex dysfunction is a feature of type 1 diabetes, which links to prognosis and mortality of the type 1 diabetic patients. The arterial baroreflex normally regulates the blood pressure and heart rate through sensing changes of arterial vascular tension by the arterial baroreceptors in the aortic arch and carotid sinus. The aortic baroreceptor neuron located in the nodose ganglia is a primary afferent component of the arterial baroreflex. The functional changes of these neurons are involved in the arterial baroreflex dysfunction in the type 1 diabetes. Type 1 diabetes causes the overexpression and hyperactivation of hyperpolarization-activated cyclic nucleotide-gated ( $\mathrm{HCN}$ ) channels and further reduces cell excitability of the aortic baroreceptor neurons. The alterations of the HCN channels are regulated by angiotensin II-NADPH oxidase-superoxide signaling in the aortic baroreceptor neurons. From the present review, we can understand the possible mechanisms responsible for the attenuated arterial baroreflex in the type 1 diabetes. These findings are beneficial for improving quality of life and prognosis in patients with the type 1 diabetes mellitus.
\end{abstract}

Keywords: Baroreflex; Baroreceptor; Ion channels; Angiotensin II; Superoxide; Diabetes

\section{Introduction}

The arterial baroreflex normally minimizes short-term oscillations in arterial blood pressure through regulating sympathetic and parasympathetic outflow [1,2]. Many studies have reported that type 1 diabetes causes the arterial baroreflex dysfunction in patients and animal models [3-16]. As a frequent complication of type 1 diabetes, the impairment of the arterial baroreflex contributes to high morbidity and mortality in type 1 diabetic patients [17-23].

In the arterial baroreflex arc, arterial baroreceptor neurons located in the nodose ganglia and petrosal ganglia are the main afferent component. These neurons sense the mechanical alteration of the arterial vascular walls through the baroreceptor terminals and increase the afferent neuronal excitation. This excited signal in the baroreceptor neurons is conveyed to the dorsal medial nucleus tractus solitary and evokes the cardio- and sympatho-inhibitory responses (such as decreasing peripheral vascular resistance and heart rate) [24-27]. Although it is possible that each component of the arterial baroreflex arc is involved in the impairment of the arterial baroreflex in type 1 diabetic condition, recent studies have indicated that the arterial baroreceptor neurons are involved in diabetes-related arterial baroreflex dysfunction [12,28,29]. The present review will mainly discuss the involvement of the arterial baroreceptor neurons in the arterial baroreflex dysfunction in type 1 diabetes, particularly the changes of arterial baroreceptor function and the possible cellular and molecular mechanisms responsible for these alterations.

\section{Morphological and Functional Alterations of the Arterial Baroreceptor Neurons in Type-1 Diabetes Mellitus}

The arterial baroreceptor neurons belong to the pseudo-unipolar neurons. This type of neurons has a soma located in the nodose or petrosal ganglia. An axon leaves the soma and further splits into two branches (30). One branch named as peripheral branch innervates the aortic arch and carotid sinus for sensing mechanical alteration of the arterial vascular wall. Other branch named as central branch projects to the nucleus tractus solitary of the medulla for conducting the electrical signals of the baroreceptor neurons to the central nervous system [30]. So far it is still unclear how changes of the arterial vascular tension are converted into the electrical signal in the baroreceptor neurons. In general, there are mechanosensitive ion channels (such as epithelial sodium channels) in the baroreceptor nerve endings innervating to the aortic arch and carotid sinus [31]. The mechanosensitive ion channels sense the alterations of the arterial vascular tension and might convert the mechanical tension into the electrical signal. In the baroreceptor neurons, the electrical signal is conducted to the nucleus tractus solitary by neuronal excitation (action potential) that is controlled by voltage-gated ion channels (including sodium, calcium, and potassium channels). Therefore, it is possible that type 1 diabetes causes these electrophysiological changes (such as ion channel properties), which link to the blunted arterial baroreflex. However, determining the mechanotransduction in the arterial baroreceptor terminals imbedded in the vascular wall requires the development of advanced techniques, not yet available [32]. The neuron somata of the arterial baroreceptors are extensively used to investigate the potential mechanisms associated to the sensitivity of the arterial baroreceptors.

Type 1 diabetes-induced pathophysiological changes of the arterial baroreceptor neurons are generally divided into morphological changes and functional changes. An endless debate still remains about type 1 diabetes-induced morphological change due to different animal models and different time course of type 1 diabetes. Guo et al.

*Corresponding author: Yu-Long Li, Department of Emergency Medicine, University of Nebraska Medical Center, Omaha, NE 68198-5850, USA, Tel: 1-402-559-3016 Fax: 1-402-559-9659; E-mail: yulongli@unmc.edu

Received March 01, 2013; Accepted March 30, 2013; Published April 05, 2013

Citation: Li YL (2013) Angiotensin II-Superoxide Signaling and Arterial Baroreceptor Function in Type-1 Diabetes Mellitus. J Diabetes Metab S12: 001. doi:10.4172/2155-6156.S12-001

Copyright: @ $2013 \mathrm{Li} \mathrm{YL}$. This is an open-access article distributed under the terms of the Creative Commons Attribution License, which permits unrestricted use, distribution, and reproduction in any medium, provided the original author and source are credited. 
have tested apoptosis in the vagus nodose ganglia using assessment of terminal deoxynucleotidyl transferase-mediated dUTP nick-end labeling (TUNEL)-positive and caspase-3-positive neurons [33]. They found that streptozotocin (STZ)-induced type 1 diabetes increased apoptotic-positive cells in the nodose ganglion neurons including the aortic baroreceptor neurons $(1.2 \pm 0.2 \%$ of total neurons from diabetic rats vs. $0.2 \pm 0.08 \%$ of total neurons from sham rats) [33]. Nevertheless, it is unclear whether low level of the apoptotic nodose neurons (about $1 \%$ of the total neuronal population [33]) can affect the sensitivity of the arterial baroreceptors in type 1 diabetes. On the other hand, some studies have confirmed that diabetes doesn't induce cell death of the nodose ganglion neurons [34], but it affects the expression of some neuroactive agents (such as increasing neuronal nitric oxide synthase-immunoreactive neurons, raising transcription factor c-Junimmunoreactive neurons, and decreasing tyrosine hydroxylaseimmunoreactive neurons) in the nodose ganglion neurons [35]. Our recent study indicates that STZ-induced type 1 diabetes doesn't alter the total cell number of the nodose ganglion neurons and the ratio of different subtype neurons [36]. Based on the above data, we consider that the impairment of the arterial baroreflex in the early stage of type 1 diabetes might be associated with the functional alterations in the baroreceptor neurons at the cellular and molecular levels but not the morphological changes. Of course, we do recognize that diabetes can induce morphological changes following the progression of type 1 diabetes.

As mentioned above, neuronal excitation is a key factor to affect the arterial baroreceptor function. Patch-clamp technique has been thought to be a feasible and powerful tool to investigate the electrophysiological properties of cell membranes in a number of the excitable cells including neuron cells. All major voltage-gated ion channels (including sodium channels, calcium channels, and potassium channels) are detected in the nodose neurons by the whole-cell patch clamp recording [37-41]. Although we understand that these voltagegated ion channels are the key factors to affect the cell excitation of the baroreceptor neurons, there is no available information about the alterations of these channels in the arterial baroreceptor neurons from type 1 diabetes. Growing evidence from animal experiments has indicated that hyperpolarization-activated cyclic nucleotide-gated (HCN) channels might be a potential candidate to influence the cell excitation of the arterial baroreceptor neurons in normal and type 1 diabetic condition [36,42-44].

The HCN channels were first reported in 1976 and it was thought to be involved in the cell automaticity in the sinoatrial node of the heart $[45,46]$. The HCN channels have been divided into HCN1, HCN2, HCN3, and HCN4 isoforms by genomic classification [4751]. Each channel isoform is also distinguished by distinct activation rates $(\mathrm{HCN} 1>\mathrm{HCN} 2>\mathrm{HCN} 3>\mathrm{HCN} 4)$ [52-56]. Additionally, some endogenous substances also modulate the HCN channel kinetics. For example, activation of the HCN channels is facilitated by cAMP and cGMP [52,56-59].

mRNA and protein of the HCN1-4 are expressed in the nodose ganglion neurons [36,47]. Additionally, the localization of HCN channel isoforms in the nodose ganglion neurons was measured by fluorescent immunohistochemistry [36,42]. Although the HCN3 and HCN4 proteins are expressed in all nodose neurons, HCN1 protein is only expressed in A-type (myelinated-fiber) nodose neurons and HCN2 protein is only expressed in C-type (non-myelinated-fiber) nodose neurons [36,42]. More importantly, the HCN channel protein is overexpressed in all nodose ganglion neurons from STZ-induced type 1 diabetic rats, compared to sham rats [36,42]. Matching with the data for the expression of HCN channels, STZ-induced type 1 diabetes significantly increases the $\mathrm{HCN}$ currents in all aortic baroreceptor neurons $[36,42,43]$.

The HCN channels are expressed in many tissues and have different physiological roles in these tissues. In the heart, the HCN channels trigger the initiation of the heart rate $[45,60,61]$. In various brain regions, the HCN channels are involved in the generation of sustained rhythmic oscillations [62-64]. In our recent studies, we found that HCN channel blockers (CsCl and ZD-7288) lower the HCN current density and raise the cell excitability in all aortic baroreceptor neurons (peripheral ganglion neurons) $[42,43]$. From our studies, we claim that the role of the HCN channels in the peripheral baroreceptors is distinct from their roles in the heart and brain. One possible reason is that the peripheral baroreceptor neurons are non-spontaneously exciting cells and their excitation needs the exciting signal from their afferent endings $[42,65]$. Additionally, STZ-induced type 1 diabetes increases the HCN currents and decreases the cell excitability in all isolated aortic baroreceptor neurons, compared to those in sham condition $[36,42,43]$. These data further confirm that activation of the HCN channels decreases the cell excitability in the baroreceptor neurons.

\section{Modulatory Effect of Angiotensin II-Superoxide Signaling on HCN Channels in the Arterial Baroreceptor Neurons from Type 1 Diabetes Mellitus}

Angiotensin (Ang) II has been recognized as a physiologically active peptide in multi tissues including nodose ganglia [66,67]. This endogenous hormone has some physiological effects such as the maintenance of blood pressure and fluid homeostasis [68]. Normally these physiological actions of Ang II are mediated by Ang II receptors located on the cells of local tissues [69]. It is known that circulating and local tissue Ang II concentrations are elevated in diabetic patients and animal models with diabetes [70-72]. Using some techniques including autoradiography, nodose ganglionectomy, and vagal ligation, Allen, et al. found that Ang II receptor binding sites existed in somata of the nodose neurons and transported to terminals of the nodose neurons $[66,73]$. Electrophysiological study revealed that exogenous Ang II has the direct neuronal effect on the nodose neurons through Ang II type $1\left(\mathrm{AT}_{1}\right)$ receptors [74]. The data from radioimmunoassay, singlecell RT-PCR, and western blot demonstrated that endogenous Ang II level and expression of $\mathrm{AT}_{1}$ receptor mRNA and protein are increased in the nodose neurons from STZ-induced type 1 diabetic rats [43]. Additionally, exogenous Ang II mimics diabetes to enhance the HCN currents and to lower the neuronal excitability in the isolated aortic baroreceptor neurons from sham rats [44]. More importantly, diabetesor exogenous Ang II-induced alterations of the HCN currents and neuronal excitability in the isolated aortic baroreceptor neurons are fully normalized by $\mathrm{AT}_{1}$ receptor antagonists (losartan and L158,809) $[43,44]$. These results demonstrate that the elevation of endogenous Ang II can attenuate excitation of the aortic baroreceptor neurons through activating $\mathrm{HCN}$ channels in type 1 diabetes.

Above electrophysiological results were obtained in the fresh dissociated single neurons. Now question is how endogenous Ang II existed in the cytosol modulates the HCN channel kinetics in a dissociated single neuron. In general, Ang II binds with AT receptors located in the cell membrane, and then induces cellular responses through activating intracellular signaling cascades. However, intracellular Ang II level was elevated in renal cortical endosomes during exogenous Ang II-induced hypertension [75]. In cardiac 
myocytes isolated from hamsters, intracellular administration of Ang II influences the electrophysiological properties of the voltagegated calcium channels and the cell junctional conductance [76,77]. Additionally, the effect of intracellular Ang II on ion channels and cell junctional conductance is abolished by intracellular treatment of losartan (a selective $\mathrm{AT}_{1}$ receptor antagonist) but not extracellular losartan [76,77]. We also observed that intracellular administration of losartan (added to the recording pipette solution) decreased the HCN current density and increased the cell excitability in the aortic baroreceptor neurons from diabetic rats [43]. Therefore, it is possible that diabetes activates an intracellular angiotensin II production system in the nodose ganglia. Of course, we couldn't neglect the effect of circulating Ang II on the neurons when we analyze and explain the effect of Ang II in the whole animal experiments or clinical phenomena.

What mechanism(s) account for Ang II-induced activation of $\mathrm{HCN}$ channels? Ang II binds with $\mathrm{AT}_{1}$ receptors to cause the superoxide production mainly through activation of NADPH oxidase [78]. NADPH oxidase is a multicomponent enzyme that produces the superoxide by the one-electron reduction of oxygen. This enzyme has two cell membrane-associated subunits (gp91 ${ }^{\text {phox }}$ and $\mathrm{p} 22^{\text {phox }}$ ), three cytosolic subunits ( $\mathrm{p} 40^{\text {phox }}, \mathrm{p} 47^{\text {phox }}$, and $\left.\mathrm{p} 67^{\text {phox }}\right)$, and the small G-proteins (Rac and Rap1a) [79,80]. As a main source of the intracellular superoxide, NADPH oxidase has been found in many tissues [8186]. Protein of the NADPH oxidase subunits is also expressed in the nodose ganglia [43]. Diabetes increases the protein expression of all NADPH oxidase subunits in the nodose ganglia [43]. NADPH oxidase inhibitors (apocynin and phenylarsine oxide) or superoxide scavengers (tempol and polyethylene glycol-superoxide dismutase) significantly inhibit diabetes- or exogenous Ang II-triggered overproduction of the superoxide, hyperactivation of the HCN channels, and suppression of the cell excitation in the aortic baroreceptor neurons $[43,44]$. The data from these studies clearly suggest that Ang II-NADPH-derived superoxide signaling regulates the neuronal excitability through influencing activation of the HCN channel in the aortic baroreceptors from type 1 diabetic rats.

Normally a low level of the superoxide in the healthy cells is produced by leakage or short circuiting of electrons [87]. This tiny amount of the superoxide is able to kill microorganisms and to clean some cellular wastes $[87,88]$. Our recent study found that superoxide scavenger (tempol and polyethylene glycol-superoxide dismutase) did not affect activation of the HCN channels and cell excitability although they inhibited basal superoxide production in the aortic baroreceptor neurons from sham rats $[43,44]$. However, after acute administration of these chemicals in the aortic baroreceptor neurons from type 1 diabetic rats, the $\mathrm{HCN}$ currents and the cell excitability were normalized to the levels seen in the sham neurons [43]. One reasonable explanation is that only a higher level of the superoxide production can modulate the electrophysiological properties of the HCN channels.

An antioxidant, $a$-lipoic acid prevents diabetes-induced arterial baroreceptor dysfunction [89]. Are all endogenous oxidants involved in the attenuation of the arterial baroreceptor function in type 1 diabetes? Several reactive oxygen species (ROS) including superoxide, hydrogen peroxide, and hydroxyl radical are biologically derived from oxygen [90]. These chemically reactive molecules are highly unstable and short-lived [90]. In general, superoxide dismutase rapidly catalyzes two superoxide anions into a molecule of hydrogen peroxide, which in turn is quickly reduced to hydroxyl radical. The electrophysiological properties of ion channels are modulated by these reactive molecules [91-93]. In the aortic baroreceptor neurons, superoxide scavengers (tempol and polyethylene glycol-superoxide dismutase) have an ability to normalize diabetes-enhanced HCN currents to the level seen in sham neurons [43]. These data indicate that overproduction of superoxide but not hydrogen peroxide and hydroxyl radical is involved in the modulation of the HCN channels in the aortic baroreceptor neurons from STZ-induced type 1 diabetic rats.

The electrophysiological properties of the ion channels can be modulated by most of the endogenous substances. The modulation of the ion channels is divided into acutely influencing the kinetics of the ion channels (such as changing activation and inactivation curves) and chronically altering the expression of the ion channels (including mRNA and protein). In the studies described above, the acute effect of Ang II-NADPH oxidase-superoxide signaling on the kinetics of the HCN channels was measured in the aortic baroreceptor neurons from sham and STZ-induced diabetic rats $[43,44]$. Our recent study found that this signaling pathway also affects the expression of the $\mathrm{HCN}$ channel protein in rat nodose neurons [94]. These findings, taken together, demonstrate that development of type 1 diabetes activates Ang II-NADPH oxidase-superoxide signaling cascade and resultant overexpression and hyperactivation of the HCN channels in the aortic baroreceptor neurons.

\section{Involvement of Ang II-Superoxide-HCN Channel Signaling in Impairment of the Arterial Baroreflex in Type 1 Diabetes Mellitus}

One recent study has shown that the impaired baroreflex sensitivity correlates with the changes in the nucleus tractus solitary neural firing rates, which is affected by both afferent nervous behavior and nucleus tractus solitary cells themselves in the STZ-induced type 1 diabetic rats [95]. The collision experiments in the rabbit nodose ganglia have found that somata and central axons of the nodose neurons modulate the visceral afferent neuronal signals to the central nervous system [96]. One review paper has concluded that nodose ganglion neurons can be able to integrate the various received signals for the modulation of vago-vagal reflex [97].

A method for evaluation of the arterial baroreflex is to examine the changes of blood pressure and heart rate induced by electrical stimulation of baroreceptor-containing nerve (aortic depressor nerve),

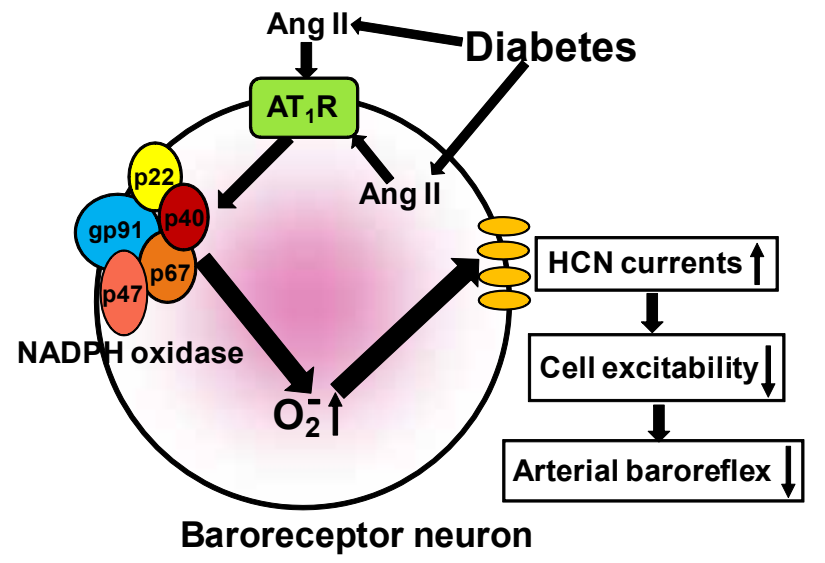

Figure 1: A schematic diagram illustrating the mechanism(s) responsible for impairment of the arterial baroreceptor neurons in type 1 diabetes. $A T_{1} R$ : Angiotensin II type-1 receptor. 
which is widely accepted by researchers [98-100]. The advantages for this method include: 1) the aortic depressor nerves of rabbits, rats, and mice contain only baroreceptor afferent fibers and no functional chemoreceptor afferent fibers for the transmission of input signals [101-104]; 2) direct electrical stimulation of the aortic depressor nerve is to bypass the mechano-viscoelastic coupling between changes in the aortic arterial vascular walls and afferent nerve endings; 3 ) easily changing the frequency and intensity of stimulus can differentiate the reflex responses to activating A- and C- afferent fibers. Our studies have shown that type 1 diabetes significantly attenuated the arterial baroreflex sensitivity measured by the reflex responses of blood pressure and heart rate to the electrical stimulation of the aortic baroreceptor nerves [12,105]. Additionally, local microinjection of exogenous Ang II into the nodose ganglion could mimic the diabetes to decrease the arterial baroreflex sensitivity [12]. Furthermore, our studies also found that microinjection of $\mathrm{AT}_{1}$ receptor antagonist, NADPH oxidase inhibitor, superoxide scavenger, or HCN channel blocker into the nodose ganglion significantly improved diabetes- or exogenous Ang II-induced impairment of the arterial baroreflex sensitivity [12,105]. These data provide the direct evidence that Ang II-superoxide-HCN channel signaling contributes to impairment of the arterial baroreflex sensitivity in STZ-induced diabetic rats.

In this review, we have updated the new information about the functional alterations of the arterial baroreceptors in type 1 diabetes. Ang II/AT 1 receptor-NADPH oxidase-superoxide signaling modulates the expression and activation of the HCN channels in the aortic baroreceptor neurons and subsequently causes the impairment of the arterial baroreflex in type 1 diabetes (Figure 1). These new findings provide potential therapies for improving the prognosis of patients with type 1 diabetes.

\section{Acknowledgments}

This study was supported by a Scientist Development Grant $0730108 \mathrm{~N}$ from American Heart Association National Center (to Y.L. Li) and by National Heart, Lung, and Blood Institute grant HL-098503 with title Dysfunction of Baroreceptor Neurons in Heart Failure: Cellular and Molecular Mechanisms.

\section{References}

1. Ganguly PK, Beamish RE, Dhalla KS, Innes IR, Dhalla NS (1987) Norepinephrine storage, distribution, and release in diabetic cardiomyopathy. Am J Physiol 252: E734-739.

2. Lund DD, Subieta AR, Pardini BJ, Chang KS (1992) Alterations in cardiac parasympathetic indices in STZ-induced diabetic rats. Diabetes 41: 160-166.

3. Bennett T, Farquhar IK, Hosking DJ, Hampton JR (1978) Assessment of methods for estimating autonomic nervous control of the heart in patients with diabetes mellitus. Diabetes 27: 1167-1174.

4. Dall'Ago P, Fernandes TG, Machado UF, Belló AA, Irigoyen MC (1997) Baroreflex and chemoreflex dysfunction in streptozotocin-diabetic rats. Braz $J$ Med Biol Res 30: 119-124.

5. Dall'Ago P, Silva VO, De Angelis KL, Irigoyen MC, Fazan R Jr, et al. (2002) Reflex control of arterial pressure and heart rate in short-term streptozotocin diabetic rats. Braz J Med Biol Res 35: 843-849.

6. Dall'ago P, D'Agord Schaan B, da Silva VO, Werner J, da Silva Soares PP, et al. (2007) Parasympathetic dysfunction is associated with baroreflex and chemoreflex impairment in streptozotocin-induced diabetes in rats. Auton Neurosci 131: 28-35.

7. Dalla Pozza R, Bechtold S, Bonfig W, Putzker S, Kozlik-Feldmann R, et al. (2007) Impaired short-term blood pressure regulation and autonomic dysbalance in children with type 1 diabetes mellitus. Diabetologia 50: 24172423.

8. De Angelis KL, Oliveira AR, Dall'Ago P, Peixoto LR, Gadonski G, et al. (2000) Effects of exercise training on autonomic and myocardial dysfunction in streptozotocin-diabetic rats. Braz J Med Biol Res 33: 635-641.
9. De Angelis K, Schaan BD, Maeda CY, Dall'Ago P, Wichi RB, et al. (2002) Cardiovascular control in experimental diabetes. Braz J Med Biol Res 35: 10911100.

10. Fazan R Jr, Ballejo G, Salgado MC, Moraes MF, Salgado HC (1997) Heart rate variability and baroreceptor function in chronic diabetic rats. Hypertension 30: $632-635$

11. Frattola A, Parati G, Gamba P, Paleari F, Mauri G, et al. (1997) Time and frequency domain estimates of spontaneous baroreflex sensitivity provide early detection of autonomic dysfunction in diabetes mellitus. Diabetologia 40: 14701475 .

12. Li YL (2011) Elevated angiotensin II in rat nodose ganglia primes diabetesblunted arterial baroreflex sensitivity: involvement of NADPH oxidase-derived superoxide. J Diabetes Metab 2.

13. Lishner M, Akselrod S, Avi VM, Oz O, Divon M, et al. (1987) Spectral analysis of heart rate fluctuations. A non-invasive, sensitive method for the early diagnosis of autonomic neuropathy in diabetes mellitus. J Auton Nerv Syst 19: 119-125.

14. Maeda CY, Fernandes TG, Timm HB, Irigoyen MC (1995) Autonomic dysfunction in short-term experimental diabetes. Hypertension 26: 1100-1104.

15. McDowell TS, Hajduczok G, Abboud FM, Chapleau MW (1994) Baroreflex dysfunction in diabetes mellitus. II. Site of baroreflex impairment in diabetic rabbits. Am J Physiol 266: H244-249.

16. Wegner JA, Lund DD, Overton JM, Edwards JG, Oda RP, et al. (1987) Select cardiovascular and metabolic responses of diabetic rats to moderate exercise training. Med Sci Sports Exerc 19: 497-503.

17. Ewing DJ, Campbell IW, Clarke BF (1980) The natural history of diabetic autonomic neuropathy. Q J Med 49: 95-108

18. Maser RE, Mitchell BD, Vinik Al, Freeman R (2003) The association between cardiovascular autonomic neuropathy and mortality in individuals with diabetes: a meta-analysis. Diabetes Care 26: 1895-1901.

19. O'Brien IA, McFadden JP, Corrall RJ (1991) The influence of autonomic neuropathy on mortality in insulin-dependent diabetes. Q J Med 79: 495-502.

20. Orchard TJ, LLoyd CE, Maser RE, Kuller LH (1996) Why does diabetic autonomic neuropathy predict IDDM mortality? An analysis from the Pittsburgh Epidemiology of Diabetes Complications Study. Diabetes Res Clin Pract 34 S165-171

21. Rathmann W, Ziegler D, Jahnke M, Haastert B, Gries FA (1993) Mortality in diabetic patients with cardiovascular autonomic neuropathy. Diabet Med 10 820-824.

22. Singh JP, Larson MG, O'Donnell CJ, Wilson PF, Tsuji H, et al. (2000) Association of hyperglycemia with reduced heart rate variability (The Framingham Heart Study). Am J Cardiol 86: 309-312.

23. Soedamah-Muthu SS, Chaturvedi N, Witte DR, Stevens LK, Porta M, et al. (2008) Relationship between risk factors and mortality in type 1 diabetic patients in Europe: the EURODIAB Prospective Complications Study (PCS) Diabetes Care 31: 1360-1366.

24. Benarroch EE (2008) The arterial baroreflex: functional organization and involvement in neurologic disease. Neurology 71: 1733-1738.

25. Czachurski J, Lackner KJ, Ockert D, Seller H (1982) Localization of neurones with baroreceptor input in the medial solitary nucleus by means of intracellular application of horseradish peroxidase in the cat. Neurosci Lett 28: 133-137.

26. Mendelowitz D, Yang M, Andresen MC, Kunze DL (1992) Localization and retention in vitro of fluorescently labeled aortic baroreceptor terminals on neurons from the nucleus tractus solitarius. Brain Res 581: 339-343.

27. Spyer KM, Lambert JH, Thomas T (1997) Central nervous system control of cardiovascular function: neural mechanisms and novel modulators. Clin Exp Pharmacol Physiol 24: 743-747.

28. Fazan VP, Salgado HC, Barreira AA (2006) Aortic depressor nerve myelinated fibers in acute and chronic experimental diabetes. Am J Hypertens 19: 153160

29. Li L, Huang C, Ai J, Yan B, Gu H, et al. (2010) Structural remodeling of vagal afferent innervation of aortic arch and nucleus ambiguus (NA) projections to cardiac ganglia in a transgenic mouse model of type 1 diabetes (OVE26). J Comp Neurol 518: 2771-2793.

30. Zhuo H, Ichikawa H, Helke CJ (1997) Neurochemistry of the nodose ganglion Prog Neurobiol 52: 79-107. 
31. Drummond HA, Welsh MJ, Abboud FM (2001) ENaC subunits are molecula components of the arterial baroreceptor complex. Ann N Y Acad Sci 940: 4247.

32. Snitsarev V, Whiteis CA, Abboud FM, Chapleau MW (2002) Mechanosensory transduction of vagal and baroreceptor afferents revealed by study of isolated nodose neurons in culture. Auton Neurosci 98: 59-63.

33. Guo C, Quobatari A, Shangguan Y, Hong S, Wiley JW (2004) Diabetic autonomic neuropathy: evidence for apoptosis in situ in the rat. Neurogastroenterol Motil 16: $335-345$

34. Sango K, Horie H, Saito H, Ajiki K, Tokashiki A, et al. (2002) Diabetes is not a potent inducer of neuronal cell death in mouse sensory ganglia, but it enhances neurite regeneration in vitro. Life Sci 71: 2351-2368.

35. Regalia J, Cai F, Helke C (2002) Streptozotocin-induced diabetes and the neurochemistry of vagal afferent neurons. Brain Res 938: 7-14.

36. Tu H, Zhang L, Tran TP, Muelleman RL, Li YL (2010) Diabetes alters protein expression of hyperpolarization-activated cyclic nucleotide-gated channel subunits in rat nodose ganglion cells. Neuroscience 165: 39-52.

37. Lancaster E, Oh EJ, Gover T, Weinreich D (2002) Calcium and calciumactivated currents in vagotomized rat primary vagal afferent neurons. J Physio 540: 543-556.

38. Li BY, Alfrey KD, Schild JH (2005) Correlation between the activation and inactivation gating profiles of the TTX-resistant $\mathrm{Na}$ + current from fluorescently identified aoric baroreceptor neurons of the adult rat. FASEB J 19: A606.

39. Li BY, Schild JH (2006) Differential distribution of voltage-gated K+ ion channels in adult rat aortic baroreceptor neurons with myelinated and unmyelinated afferent fibre. FASEB J 20: A775

40. Schild JH, Li BY (2001) The N-type Ca2+ current is not responsible for the repolarization 'hump' in the action potential of nodose sensory neurons. FASEB J 15: A1150.

41. Tatalovic M, Glazebrook PA, Kunze DL (2012) Expression of the P/Q (Cav2.1) calcium channel in nodose sensory neurons and arterial baroreceptors. Neurosci Lett 520: 38-42.

42. Li YL, Tran TP, Muelleman R, Schultz HD (2008) Blunted excitability of aortic baroreceptor neurons in diabetic rats: involvement of hyperpolarizationactivated channel. Cardiovasc Res 79: 715-721.

43. Li YL, Zheng H (2011) Angiotensin II-NADPH oxidase-derived superoxide mediates diabetes-attenuated cell excitability of aortic baroreceptor neurons. Am J Physiol Cell Physiol 301: C1368-1377.

44. Zhang L, Tu H, Li YL (2010) Angiotensin II enhances hyperpolarization-activated currents in rat aortic baroreceptor neurons: involvement of superoxide. Am J Physiol Cell Physiol 298: C98-98C106.

45. Brown HF, DiFrancesco D, Noble SJ (1979) How does adrenaline accelerate the heart? Nature 280: 235-236.

46. Noma A, Irisawa $\mathrm{H}$ (1976) Membrane currents in the rabbit sinoatrial node cell as studied by the double microelectrode method. Pflugers Arch 364: 45-52

47. Doan TN, Stephans K, Ramirez AN, Glazebrook PA, Andresen MC, et al. (2004) Differential distribution and function of hyperpolarization-activated channels in sensory neurons and mechanosensitive fibers. J Neurosci 24: 3335-3343.

48. Ishii TM, Takano M, Xie LH, Noma A, Ohmori H (1999) Molecular characterization of the hyperpolarization-activated cation channel in rabbit heart sinoatrial node. J Biol Chem 274: 12835-12839.

49. Ludwig A, Zong X, Jeglitsch M, Hofmann F, Biel M (1998) A family of hyperpolarization-activated mammalian cation channels. Nature 393: 587-591.

50. Santoro B, Liu DT, Yao H, Bartsch D, Kandel ER, et al. (1998) Identification of a gene encoding a hyperpolarization-activated pacemaker channel of brain. Cell 93: 717-729.

51. Vaccari T, Moroni A, Rocchi M, Gorza L, Bianchi ME, et al. (1999) The human gene coding for HCN2, a pacemaker channel of the heart. Biochim Biophys Acta 1446: 419-425.

52. Accili EA, Proenza C, Baruscotti M, DiFrancesco D (2002) From funny curren to HCN channels: 20 years of excitation. News Physiol Sci 17: 32-37.

53. Altomare C, Bucchi A, Camatini E, Baruscotti M, Viscomi C, et al. (2001) Integrated allosteric model of voltage gating of HCN channels. J Gen Physiol 117: 519-532.
54. Moosmang S, Stieber J, Zong X, Biel M, Hofmann F, et al. (2001) Cellula expression and functional characterization of four hyperpolarization-activated pacemaker channels in cardiac and neuronal tissues. Eur J Biochem 268 1646-1652.

55. Stieber J, Thomer A, Much B, Schneider A, Biel M, et al. (2003) Molecula basis for the different activation kinetics of the pacemaker channels HCN2 and HCN4. J Biol Chem 278: 33672-33680.

56. Stieber J, Stöckl G, Herrmann S, Hassfurth B, Hofmann F (2005) Functional expression of the human HCN3 channel. J Biol Chem 280: 34635-34643.

57. Biel M, Wahl-Schott C, Michalakis S, Zong X (2009) Hyperpolarization-activated cation channels: from genes to function. Physiol Rev 89: 847-885.

58. Wahl-Schott C, Biel M (2009) HCN channels: structure, cellular regulation and physiological function. Cell Mol Life Sci 66: 470-494.

59. Wang J, Chen S, Siegelbaum SA (2001) Regulation of hyperpolarizationactivated $\mathrm{HCN}$ channel gating and cAMP modulation due to interactions of $\mathrm{COOH}$ terminus and core transmembrane regions. J Gen Physiol 118: $237-$ 250

60. DiFrancesco D (1993) Pacemaker mechanisms in cardiac tissue. Annu Rev Physiol 55: 455-472.

61. Kaupp UB, Seifert R (2001) Molecular diversity of pacemaker ion channels Annu Rev Physiol 63: 235-257.

62. Notomi T, Shigemoto $R(2004)$ Immunohistochemical localization of Ih channe subunits, HCN1-4, in the rat brain. J Comp Neurol 471: 241-276.

63. Pape HC (1996) Queer current and pacemaker: the hyperpolarization-activated cation current in neurons. Annu Rev Physiol 58: 299-327.

64. Robinson RB, Siegelbaum SA (2003) Hyperpolarization-activated cation currents: from molecules to physiological function. Annu Rev Physiol 65: 453480.

65. Doan TN, Kunze DL (1999) Contribution of the hyperpolarization-activated current to the resting membrane potential of rat nodose sensory neurons. Physiol 514: 125-138.

66. Allen AM, Lewis SJ, Verberne AJ, Mendelsohn FA (1988) Angiotensin receptors and the vagal system. Clin Exp Hypertens A 10: 1239-1249.

67. Touyz RM (2005) Reactive oxygen species as mediators of calcium signaling by angiotensin II: implications in vascular physiology and pathophysiology. Antioxid Redox Signal 7: 1302-1314.

68. Peach MJ (1977) Renin-angiotensin system: biochemistry and mechanisms of action. Physiol Rev 57: 313-370.

69. Mehta PK, Griendling KK (2007) Angiotensin II cell signaling: physiological and pathological effects in the cardiovascular system. Am J Physiol Cell Physio 292: C82-97.

70. Frustaci A, Kajstura J, Chimenti C, Jakoniuk I, Leri A, et al. (2000) Myocardial cell death in human diabetes. Circ Res 87: 1123-1132

71. Sechi LA, Griffin CA, Schambelan M (1994) The cardiac renin-angiotensin system in STZ-induced diabetes. Diabetes 43: 1180-1184.

72. Shimoni Y, Liu XF (2004) Gender differences in ANG II levels and action on multiple K+ current modulation pathways in diabetic rats. Am J Physiol Heart Circ Physiol 287: H311-319.

73. Allen AM, McKinley MJ, Oldfield BJ, Dampney RA, Mendelsohn FA (1988) Angiotensin II receptor binding and the baroreflex pathway. Clin Exp Hypertens A 10: $63-78$

74. Widdop RE, Krstew E, Jarrott B (1992) Electrophysiological responses of angiotensin peptides on the rat isolated nodose ganglion. Clin Exp Hypertens A 14: $597-613$

75. Zhuo JL, Imig JD, Hammond TG, Orengo S, Benes E, et al. (2002) Ang I accumulation in rat renal endosomes during Ang Il-induced hypertension: role of AT(1) receptor. Hypertension 39: 116-121.

76. De Mello WC (2003) Further studies on the effect of intracellular angiotensins on heart cell communication: on the role of endogenous angiotensin II. Regul Pept 115: 31-36.

77. De Mello WC, Monterrubio J (2004) Intracellular and extracellular angiotensin I enhance the L-type calcium current in the failing heart. Hypertension 44: 360 364 
Citation: Li YL (2013) Angiotensin II-Superoxide Signaling and Arterial Baroreceptor Function in Type-1 Diabetes Mellitus. J Diabetes Metab S12: 001. doi:10.4172/2155-6156.S12-001

78. Touyz RM, Berry C (2002) Recent advances in angiotensin II signaling. Braz J Med Biol Res 35: 1001-1015.

79. Kim S, Iwao H (2000) Molecular and cellular mechanisms of angiotensin IImediated cardiovascular and renal diseases. Pharmacol Rev 52: 11-34.

80. Lassègue $B$, Clempus RE (2003) Vascular NAD(P)H oxidases: specific features, expression, and regulation. Am J Physiol Regul Integr Comp Physiol 285: R277-297.

81. Cifuentes ME, Rey FE, Carretero OA, Pagano PJ (2000) Upregulation of p67(phox) and gp91(phox) in aortas from angiotensin II-infused mice. Am J Physiol Heart Circ Physiol 279: H2234-2240.

82. Franco Mdo C, Akamine EH, Di Marco GS, Casarini DE, Fortes ZB, et al. (2003) NADPH oxidase and enhanced superoxide generation in intrauterine undernourished rats: involvement of the renin-angiotensin system. Cardiovasc Res 59: 767-775

83. Gao L, Wang W, Li YL, Schultz HD, Liu D, et al. (2004) Superoxide mediates sympathoexcitation in heart failure: roles of angiotensin II and $N A D(P) H$ oxidase. Circ Res 95: 937-944.

84. Griendling KK, Sorescu D, Ushio-Fukai M (2000) NAD(P)H oxidase: role in cardiovascular biology and disease. Circ Res 86: 494-501.

85. Li YL, Gao L, Zucker IH, Schultz HD (2007) NADPH oxidase-derived superoxide anion mediates angiotensin II-enhanced carotid body chemoreceptor sensitivity in heart failure rabbits. Cardiovasc Res 75: 546-554.

86. Schieffer B, Luchtefeld M, Braun S, Hilfiker A, Hilfiker-Kleiner D, et al. (2000) Role of $\mathrm{NAD}(\mathrm{P}) \mathrm{H}$ oxidase in angiotensin II-induced JAK/STAT signaling and cytokine induction. Circ Res 87: 1195-1201.

87. McCord JM (1993) Human disease, free radicals, and the oxidant/antioxidant balance. Clin Biochem 26: 351-357.

88. Fattman CL, Schaefer LM, Oury TD (2003) Extracellular superoxide dismutase in biology and medicine. Free Radic Biol Med 35: 236-256.

89. Gouty S, Regalia J, Cai F, Helke CJ (2003) Alpha-lipoic acid treatment prevents the diabetes-induced attenuation of the afferent limb of the baroreceptor reflex in rats. Auton Neurosci 108: 32-44.

90. Nordberg J, Arnér ES (2001) Reactive oxygen species, antioxidants, and the mammalian thioredoxin system. Free Radic Biol Med 31: 1287-1312.

91. Hool LC, Corry B (2007) Redox control of calcium channels: from mechanisms to therapeutic opportunities. Antioxid Redox Signal 9: 409-435.

92. Eisenhut M, Wallace $\mathrm{H}$ (2011) lon channels in inflammation. Pflugers Arch 461 401-421.
93. Sesti F, Liu S, Cai SQ (2010) Oxidation of potassium channels by ROS: general mechanism of aging and neurodegeneration? Trends Cell Biol 20: 4551.

94. Liu J, Zhang L, Tu H, Li YL (2012) Angiotensin II induces protein overexpression of hyperpolarization-activated cyclic nucleotide-gated channels in primary cultured nodose neurons. Neurosci Lett 515: 168-173.

95. Chen HY, Wu JS, Chen JJ, Cheng JT (2008) Impaired regulation function in cardiovascular neurons of nucleus tractus solitarii in streptozotocin-induced diabetic rats. Neurosci Lett 431: 161-166.

96. Ducreux C, Reynaud JC, Puizillout JJ (1993) Spike conduction properties of T-shaped $C$ neurons in the rabbit nodose ganglion. Pflugers Arch 424: 238-244.

97. Browning KN (2003) Excitability of nodose ganglion cells and their role in vagovagal reflex control of gastrointestinal function. Curr Opin Pharmacol 3: 613617.

98. Fan W, Andresen MC (1998) Differential frequency-dependent reflex integration of myelinated and nonmyelinated rat aortic baroreceptors. Am J Physiol 275 H632-640.

99. Salgado HC, Barale AR, Castania JA, Machado BH, Chapleau MW, et al. (2007) Baroreflex responses to electrical stimulation of aortic depressor nerve in conscious SHR. Am J Physiol Heart Circ Physiol 292: H593-600.

100.Tang X, Dworkin BR (2007) Baroreflexes of the rat. V. Tetanus-induced potentiation of ADN A-fiber responses at the NTS. Am J Physiol Regul Integr Comp Physiol 293: R2254-2259.

101. Fan W, Reynolds PJ, Andresen MC (1996) Baroreflex frequency-response characteristics to aortic depressor and carotid sinus nerve stimulation in rats. Am J Physiol 271: H2218-2227.

102. Kobayashi M, Cheng ZB, Tanaka K, Nosaka S (1999) Is the aortic depressor nerve involved in arterial chemoreflexes in rats? J Auton Nerv Syst 78: 38-48.

103. Sapru HN, Krieger AJ (1977) Carotid and aortic chemoreceptor function in the rat. J Appl Physiol 42: 344-348.

104. Sapru HN, Gonzalez E, Krieger AJ (1981) Aortic nerve stimulation in the rat cardiovascular and respiratory responses. Brain Res Bull 6: 393-398.

105. Li Y, Tran TP, Muelleman RL, Schultz HD (2008) Elevated angiotensin II in rat nodose ganglia mediates diabetes-blunted arterial baroreflex sensitivity. Circulation 118: S360. 